\title{
In vitro anti-HIV activity of some Indian medicinal plant extracts
}

Aparna Palshetkar ${ }^{1}$, Navin Pathare ${ }^{2}$, Nutan Jadhav², Megha Pawar ${ }^{2}$, Ashish Wadhwani ${ }^{2}$, Smita Kulkarni ${ }^{2 *}$ and Kamalinder K. Singh ${ }^{1,3^{*}}$

\begin{abstract}
Background: Human Immunodeficiency Virus (HIV) persists to be a significant public health issue worldwide. The current strategy for the treatment of HIV infection, Highly Active Antiretroviral Therapy (HAART), has reduced deaths from AIDS related disease, but it can be an expensive regime for the underdeveloped and developing countries where the supply of drugs is scarce and often not well tolerated, especially in persons undergoing long term treatment. The present therapy also has limitations of development of multidrug resistance, thus there is a need for the discovery of novel anti-HIV compounds from plants as a potential alternative in combating HIV disease.

Methods: Ten Indian medicinal plants were tested for entry and replication inhibition against laboratory adapted strains HIV-1 IIIB, $_{1}$ HIV-1 $1_{\text {Adas }}$ and primary isolates HIV-1 UG070, $_{\text {HIV- }} 1_{V B 59}$ in TZM-bl cell lines and primary isolates HIV$1_{\text {UG070, }}$ HIV-1 $1_{\text {VB59 }}$ in PM1 cell lines. The plant extracts were further evaluated for toxicity in HEC-1A epithelial cell lines by transwell epithelial model.

Results: The methanolic extracts of Achyranthes aspera, Rosa centifolia and aqueous extract of Ficus benghalensis inhibited laboratory adapted HIV-1 strains $\left(I_{80} 3.6-118 \mu \mathrm{g} / \mathrm{ml}\right)$ and primary isolates $\left(\mathrm{IC}_{80} 4.8-156 \mu \mathrm{g} / \mathrm{ml}\right)$ in TZM-bl cells. Methanolic extract of Strychnos potatorum, aqueous extract of Ficus infectoria and hydroalcoholic extract of Annona squamosa inhibited laboratory adapted HIV-1 strains ( $\left(\mathrm{C}_{80} 4.24-125 \mathrm{\mu g} / \mathrm{ml}\right)$ and primary isolates $\left(\mathrm{IC}_{80}{ }^{18-}\right.$ $156 \mu \mathrm{g} / \mathrm{ml})$ in TZM-bl cells. Methanolic extracts of Achyranthes aspera and Rosa centifolia, $\left(\mathrm{IC}_{80} 1-9 \mu \mathrm{g} / \mathrm{ml}\right)$ further significantly inhibited HIV-1 primary isolates in PM1cells. Methanolic extracts of Tridax procumbens, Mallotus philippinensis, Annona reticulate, aqueous extract of Ficus benghalensis and hydroalcoholic extract of Albizzia lebbeck did not exhibit anti-HIV activity in all the tested strains. Methanolic extract of Rosa centifolia also demonstrated to be non-toxic to HEC-1A epithelial cells and maintained epithelial integrity (at $500 \mu \mathrm{g} / \mathrm{ml}$ ) when tested in transwell dual-chamber.
\end{abstract}

Conclusion: These active methanolic extracts of Achyranthes aspera and Rosa centifolia, could be further subjected to chemical analysis to investigate the active moiety responsible for the anti-HIV activity. Methanolic extract of Rosa centifolia was found to be well tolerated maintaining the epithelial integrity of HEC-1A cells in vitro and thus has potential for investigating it further as candidate microbicide.

Keywords: HIV, TZM-b1, PM1, Achyranthes aspera, Rosa centifolia

\footnotetext{
*Correspondence: ksingh1@uclan.ac.uk; kksingh35@hotmail.com;

skulkarni@nariindia.org

${ }^{2}$ National AIDS Research Institute, 73, 'G'-Block, MIDC, Bhosari, Pune 411 026,

India

${ }^{3}$ School of Pharmacy and Biomedical Sciences, Faculty of Clinical and

Biomedical Sciences, University of Central Lancashire, Preston PR1 2HE, UK

Full list of author information is available at the end of the article
}

(c) The Author(s). 2020 Open Access This article is distributed under the terms of the Creative Commons Attribution 4.0 International License (http://creativecommons.org/licenses/by/4.0/), which permits unrestricted use, distribution, and reproduction in any medium, provided you give appropriate credit to the original author(s) and the source, provide a link to the Creative Commons license, and indicate if changes were made. The Creative Commons Public Domain Dedication waiver (http://creativecommons.org/publicdomain/zero/1.0/) applies to the data made available in this article, unless otherwise stated. 


\section{Background}

Human Immunodeficiency Virus (HIV) persists to be a significant public health issue worldwide. In 2018, 37.9 million people are living with HIV globally; out of which 36.2 million are adults and 1.7 million are children less than 15 years old. There were 1.7 million new infections and 770,000 people died from AIDS related illness worldwide [1]. The current strategy for the treatment of HIV infection is Highly Active Antiretroviral Therapy (HAART), based on combination of inhibitors of reverse transcriptase and protease. Although HAART has considerably reduced deaths from AIDS related disease, it often has side effects and not well tolerated especially in persons undergoing long term treatment and maintains the risk of developing multidrug resistance [2]. Moreover, HAART is an expensive regime for underdeveloped and developing countries where the drugs are inaccessible to the HIV infected patients. Thus, there is a need for the discovery of novel therapeutic strategies, which identify new anti-HIV compounds from natural sources particularly from medicinal plants.

Natural sources provide a large reservoir for screening of anti-HIV agents with novel structure and antiviral mechanism due to their structural diversity. For the purpose of this study, ten Indian traditional medicinal plants, Albizzia lebbeck, Tridax procumbens, Achyranthes aspera, Ficus benghalensis, Mallotus philippinensis, Rosa centifolia, Strychnos potatorum, Annona reticulate, Ficus infectoria and Annona squamosa were selected to investigate their in vitro inhibitory activity against entry inhibition/ replication of HIV-1 as first step towards identification of potential anti-HIV microbicide. The microbicides provide protection by directly inactivating HIV or preventing HIV from attaching, entering or replicating in susceptible target cells as well as dissemination from target cells present in semen or the host cells that line the vaginal/rectal wall [3]. These plants were selected on the basis of detailed patent survey and scientific articles on the ethnomedicinal usages of the plant genera directly in HIV/AIDS or for symptoms/conditions closely associated with this disease (Table 1).

Plants such as $R$. centifolia, S. potatorum, F. infectoria, F. benghalensis and $M$. philippinensis were selected because other species of the same genera have exhibited anti-HIV activity [56-60]. Its traditional use in gonorrhoea and leukeorrhea [61] and suppressive effects on sperm motility [39] further made $S$. potatorum, a plant of choice for this study. Fruit pulp of A. squamosa has been reported to inhibit HIV replication significantly in H9 lymphocytes [49] therefore the seeds of $A$. squamosa which have also shown spermicidal property, an additional desirable attribute for a vaginal microbicide [62] was selected for the study. In addition the leaves of other species $A$. reticulate were also selected for assessing the anti-HIV activity.
Taylor et al., [63, 64] reported methanolic extract of $T$. procumbens to exhibit in-vitro anti-Herpes Simplex Virus activity in Vero cells; hence it was selected for investigating its anti-HIV activity. Anticipating the potential of spermicide-based vaginal contraceptives in the reproductive health of women such as Nonoxynol (N-9) and Praneem polyherbal (Azadirachta indica leaves, Sapindus mukerossi pericarp of fruit and Mentha citrate oil) [65]; two plant extracts, methanolic leaf extract of $A$. aspera that has exhibited safety as well as good antifertility property [66] and methanolic pod extract of $A$. lebbeck which has been shown to suppress spermatogenesis and alter the structure and activity of the Sertoli and Leydig cells [4] were considered worthwhile to explore for anti-HIV activity.

Therefore, under the DBT-ICMR sponsored programme (HIV/AIDS and Microbicides, Phase I) developed for screening plant derived HIV microbicidal candidates, we evaluated these 10 plant extracts against 2 CXCR4 (HIV-1 $1_{\text {IIIB }}, \mathrm{HIV}$ $\left.1_{\mathrm{UG070}}\right)$ and 2 CCR5 tropic $\left(\mathrm{HIV}-1_{\mathrm{Ada} 5}, \mathrm{HIV}-1_{\mathrm{VB} 59}\right) \mathrm{HIV}-1$ strains.

\section{Methods}

\section{Plant materials and extraction}

10 plant materials were collected from various parts of India in different seasons. A plant taxonomist at publicly available herbarium, Botanical Survey of India, Pune, India, validated scientific names and classification of these plants. The specimens were also deposited in the herbarium. Table 2 presents ethno-botanical information and solvents used for extraction of the selected plants.

The collected plant materials were cleaned, freed of foreign contaminates and washed with water, first air dried and then dried in an electric oven at $40{ }^{\circ} \mathrm{C}$. The dried plant materials were pulverized in an electric mixer. The plant materials were extracted with various solvents individually by hot continuous Soxhlet extraction method for 18-24h. After extraction, the extract obtained was filtered through $0.2-\mu \mathrm{m}$ syringe filter and then concentrated on a rotary evaporator by distilling off the solvent under vacuum at $40{ }^{\circ} \mathrm{C}$. The concentrated extracts was finally lyophilized to obtain free flowing powder and stored in airtight bottles in the refrigerator at $4-8{ }^{\circ} \mathrm{C}$. The extractive yields of the individual extracts are recorded in Table 2 . Powder was reconstituted in DMSO for final concentration of extract $10 \mathrm{mg} / \mathrm{ml}$ and stored at $-20^{\circ} \mathrm{C}$ until tested for anti-HIV1 activity.

\section{Preliminary phytochemical investigation}

Qualitative tests were carried out to ascertain the presence of various phytochemicals in the plants extract of the selected plants using the methods described by Harbourne [67] (Table 3). It involved the appropriate addition of chemicals and reagents to the 
Table 1 Ethnomedicinal usages of selected plant materials

\begin{tabular}{|c|c|c|c|c|}
\hline $\mathrm{SrNo}$ & Botanical name & Common name & Family & Conventional use and published reports \\
\hline 1 & Albizzia lebbeck & Shirisha & Mimosaceae & $\begin{array}{l}\text { Bark: Anti-oxidant, anti-fertility, anti- microbial activity } \\
\text { Seeds: Anti-inflammatory activity }[4,5] .\end{array}$ \\
\hline 2 & Tridax procumbens & Ghamra & Asteraceae & $\begin{array}{l}\text { Whole plant: Anti-microbial } \\
\text { Flowers, Leaves: Anti septic, insecticidal, parasiticidal, } \\
\text { anti-Cancer Activity } \\
\text { Aerial parts: Hepatoprotective } \\
\text { Leaves: Hypotensive, anti- diabetic, } \\
\text { immunomodulating activity [6-12]. }\end{array}$ \\
\hline 3 & Achyranthes aspera & Apaamaarga & Amaranthaceae & $\begin{array}{l}\text { Whole plant: Nephroprotective, hypolepidemic activity. } \\
\text { Roots: anti-oxidant, spermicidal, activity } \\
\text { Leaves: anti-oxidant, anti-fertility, anti-depressant, } \\
\text { anti-cancer, anti- microbial activity } \\
\text { Aerial parts: Hepatoprotective activity } \\
\text { Seeds: Anti- microbial activity [13-22]. }\end{array}$ \\
\hline 4 & Ficus benghalensis & Vad & Moraceae & $\begin{array}{l}\text { Whole plant: anthelmentic, anti-bacterial activity. } \\
\text { Bark: Anti-inflammatory, anti-bacterial activity. } \\
\text { Aerial roots: anti-oxidant, anti-diabetic, } \\
\text { immunomodulatory activity [23-27]. }\end{array}$ \\
\hline 5 & Ficus infectoria & Pilkhan & & $\begin{array}{l}\text { Bark and Leaves: anti-oxidant, } \\
\text { anti-hyperlipidemic, hypoglycemic activity [28]. }\end{array}$ \\
\hline 6 & Mallotus philippinensis & Kamala & Euphorbiaceae & $\begin{array}{l}\text { Seeds: Anti-fertility activity. } \\
\text { Stembark: anti-oxidant, anti-tumor activity, } \\
\text { anti- bacterial. } \\
\text { Fruits: anti-inflammatory, immunoregulatory, } \\
\text { anti-proliferative activity. } \\
\text { Leaves: Hepatoprotective activity } \\
\text { Roots: Anti-leukaemic activity [29-36]. }\end{array}$ \\
\hline 7 & Rosa centifolia & Gulab & Rosaceae & $\begin{array}{l}\text { Leaves: treating wounds, ophthalmia, hepatopathy, } \\
\text { hemorrhoids and anti-microbial, } \\
\text { Flowers: cardio tonic, anti-inflammatory, anti-asthmatic, } \\
\text { anti-bronchitic, anti-diarrheal, dysmenorrheal, urinary } \\
\text { tract infections, anti-tussive activity [37, 38]. }\end{array}$ \\
\hline 8 & Strychnos potatorum & Nirmali & Loganiaceae & $\begin{array}{l}\text { Plant: Anti-diabetic, anti- microbial activity } \\
\text { Seeds: Contraceptive, diuretic, anti-inflammatory, } \\
\text { hepatoprotective, antioxidant, antiarthritic } \\
\text { activity [39-45]. }\end{array}$ \\
\hline 9 & Annona reticulate & Ramphal & Annonaceae & $\begin{array}{l}\text { Leaves: Anti-oxidant, anti- inflammatory, anti-helmentic } \\
\text { activity. } \\
\text { Seeds: Anti-cancer [46-48]. }\end{array}$ \\
\hline 10 & Annona squamosa & Sitafal & & $\begin{array}{l}\text { Bark: Anti-malarial activity } \\
\text { Seeds: Anti-tumor activity } \\
\text { Twigs: Anti-ulcer activity } \\
\text { Leaves: anti- oxidant,hepatoprotective, anti- bacterial } \\
\text { activity } \\
\text { Fruit pulp: Anti-HIV activity [49-55]. }\end{array}$ \\
\hline
\end{tabular}

Legend: Details of plants selected and their reported conventional use

concentrated extract of the plant material in a test tube. The changes in the appearance of the colour, as the case may be, confirmed the presence of alkaloids, flavanoids, tannins, steroids and saponins.

\section{Cells, viral strain and culture conditions}

TZM-bl (recombinant HeLa cells expressing high levels CD4 receptor, CXCR4 and CCR5 co-receptors) and PM1 cells (Clonal derivative of HUT 78) were obtained from the National Institutes of Health AIDS Research and Reference Reagent Program (NIH ARRRP). The HEC-1A (human endometrial adenocarcinoma) cell line was kindly provided by Dr. R. Fichorova (Associate Professor, Brigham and Women's Hospital, Boston, USA) and National Institute of Virology, Pune, respectively.

The TZM-bl cells were maintained in Dulbecco's modified Eagle's medium (DMEM, Sigma-Aldrich, USA) and PM1 and HEC-1A cells in RPMI-1640 (Sigma-Aldrich, USA), supplemented with $10 \%$ heat inactivated fetal bovine serum (FBS, Moregate Biotech, Australia) and standard antibiotic-antimycotic cocktail. 
Table 2 Procurement, authentication and solvents used for extraction of plant material

\begin{tabular}{|c|c|c|c|c|c|}
\hline Sr. No. & Plant Name & Part of plant & Authentication No. & Solvent for extraction & $\%$ yield $( \pm$ SD) \\
\hline 1 & Albizzia lebbeck & Whole pods & RR 3794 & Hydroalcohol & $17.20( \pm 0.32)$ \\
\hline 2 & Tridax procumbens & Aerial parts & KK1 & Methanol & $7.2( \pm 1.32)$ \\
\hline 3 & Achyranthes aspera & Aerial parts & PADAAP1 & Methanol & $10.74( \pm 0.02)$ \\
\hline 4 & Ficus benghalensis & Leaves & PADFB1 & Water & $7.56( \pm 0.52)$ \\
\hline 5 & Mallotus philippinensis & Leaves & MPADP12 & Methanol & $5.72( \pm 0.09)$ \\
\hline 6 & Rosa centifolia & Leaves & ROAP1 & Methanol & $9.46( \pm 0.56)$ \\
\hline 7 & Strychnos potatorum & Seeds & SPAP2 & Methanol & $15.00( \pm 0.43)$ \\
\hline 8 & Annona reticulata & Leaves & APAR1 & Methanol & $7.89( \pm 0.07)$ \\
\hline 9 & Ficus infectoria & Leaves & APF1 & Water & $19.08( \pm 0.02)$ \\
\hline 10 & Annona squamosa & Seeds & SS1/ 2008 & Hydroalcohol & $10.87( \pm 0.15)$ \\
\hline
\end{tabular}

Legend: Procurement, authentication no. \& extraction details of the plants parts used for the study

The laboratory adapted HIV-1 strains [HIV-1IIIB (X4, subtype B), HIV-1Ada5 (R5, subtype B)] and the primary isolate HIV-1UG070 (X4, Subtype D) were procured from National Institutes of Health-AIDS Research and Reference Reagent Program, while the Indian isolate HIV-1VB59 (R5, subtype C) was obtained from the National AIDS Research Institute (NARI), Pune. Phytohemagglutinin-P $(5 \mu \mathrm{g} / \mathrm{ml}$, Sigma Aldrich, USA) activated peripheral blood mononuclear cells (PBMC) derived from healthy donors were used for the growth of all the viral strains. HIV-1 p24 antigen detection kit (Vironostika HIV-1 Antigen, Netherlands) was used to determine the virus production in cell culture supernatants. Samples of viral culture supernatants free form cells were obtained by centrifugation and further filtered and finally stored at $-70 \mathrm{oC}$ for further use. Spearman Karber formula was used to ascertain the
$50 \%$ tissue culture infectivity dose (TCID50) of each virus stock in both TZM-bl and PM1 cells [68].

\section{Anti HIV1 assays \\ Determination of cytotoxicity in the uninfected TZM-bl and PM1 cell lines}

The cytotoxicity of the extracts was determined in uninfected TZM-bl cells using colorimetric assay that measures the reduction of a yellow 3-(4,5-dimethythiazol-2-yl)-2,5-diphenyl tetrazolium bromide (MTT) by mitochondrial succinate dehydrogenase (Sigma Aldrich, USA) [69]. Briefly, two-fold dilutions of the extracts were prepared, added to 96 well plates pre-seeded with TZM-bl cells $(10,000$ cells/well) in quadruplicate and incubated for $48 \mathrm{~h}$ at $37^{\circ} \mathrm{C}$. The MTT $(20 \mu \mathrm{l}, 5 \mathrm{mg} / \mathrm{ml})$ solution was added and the plates were incubated

Table 3 Phytochemical screening of selected plant extracts

\begin{tabular}{|c|c|c|c|c|c|c|}
\hline Sr. No. & Plant Extracts & Steriods & Saponins & Flavanoids & Alkaloids & Tannins/ Phenolic Compounds \\
\hline 1 & A. lebbeck & +++ & + & + & ++++ & ++ \\
\hline 2 & T. procumbens & - & - & + & - & - \\
\hline 3 & A. aspera & +++ & + & + & ++++ & ++++ \\
\hline 4 & F. benghalensis & +++ & + & + & ++++ & +++ \\
\hline 5 & M. philippinensis & - & + & + & ++++ & ++ \\
\hline 6 & R. centifolia & - & + & + & ++++ & ++ \\
\hline 7 & S. potaotorum & +++ & + & - & ++++ & ++ \\
\hline 8 & A. reticulate & +++ & - & + & ++++ & +++ \\
\hline 9 & F. infectoria & ++ & + & ++ & ++++ & ++++ \\
\hline 10 & A. squamosa & - & + & + & ++++ & ++ \\
\hline
\end{tabular}

Legend: presence or absence of phytochemical components in plant extracts by different methods

-: Absent, ++++: Present in large proportion, +++: Present in good proportion, ++: Present in moderate proportion, +: Present in low proportion

Tests for Steroid: 1. Salkowski Reaction 2. Liebermann- Burchard Reaction 3. Liebermann's Reaction

Tests for Saponins: 1. Foam Test

Tests for Flavanoids: 1. Shinoda Test 2. Lead acetate Test

Test for Alkaloids: 1. Dragendorff's Test 2. Mayer's Test 3. Hager's Test 4. Wagner's Test

Test for Tannins and Phenolic compounds: 1. 5\% Ferric Chloride 2. Dilute lodine Solution 3. Lead acetate solution 4. Dilute Potassium permanganate solution 
further for $4 \mathrm{~h}$. The supernatant was removed, $200 \mu \mathrm{l}$ of DMSO was added, the plates were incubated for $1 \mathrm{~h}$ and the absorbance was read at $550 \mathrm{~nm}$ and $630 \mathrm{~nm}$. The percent viability was calculated by comparing cell viability in the absence of extract using following formula and the results were expressed as $\mathrm{CC}_{50}$ (50\% cytotoxic concentration).

$\%$ Cell Viability $=[$ OD test extract $/$ Average OD control $] \times 100$

The cytotoxicity in uninfected PM1 cells of all the extracts was determined in a similar manner by using a similar dilution scheme and procedure as mentioned above for TZM-bl cells. The cell viability was determined by the trypan blue dye exclusion assay (Sigma Aldrich, USA) and the results were expressed as $\mathrm{CC}_{50}[70]$.

\section{Preliminary screening for anti-HIV1 activity against laboratory adapted strains in TZM-bl cell lines}

The anti-HIV1 activity was tested against Cell-free (CF) and Cell-associated (CA) X4 tropic (HIV-1 IIIB) and R5 tropic $\left(\mathrm{HIV}-1_{\mathrm{Ada}}\right)$ laboratory adapted strains in TZMb1 cell lines.

In cell free assay, the viral stocks $\left(400 \mathrm{TCID}_{50}\right)$ were pre-treated in duplicate with sub toxic concentrations of the extracts/fractions for $1 \mathrm{~h}$, at $37^{\circ} \mathrm{C}$ prior to addition onto the TZM-bl cells (10,000 cells/well). While in cell-associated assay, the cells $(10,000$ cells/ well) were pre-infected with the viral stocks $(400$ $\mathrm{TCID}_{50}$ ) for $2 \mathrm{~h}$ at $37^{\circ} \mathrm{C}$ before exposure to the extracts/fractions [71]. After $48 \mathrm{~h}$, the supernatant was collected and luciferase activity was determined using Britelite plus (Perkin Elmer, USA). Dextran Sulphate (Sigma Aldrich, USA) and Azidothymidine (AZT, CIPLA, India) were used as positive controls for cell free and cell associated assays respectively. The results were expressed as $\mathrm{IC}_{50}$ (50\% inhibitory concentration), $\mathrm{IC}_{80}$ (80\% inhibitory concentration) and Therapeutic Index $\left(\mathrm{TI}=\mathrm{CC}_{50} / \mathrm{IC}_{50}\right)$.

\section{Confirmation of anti-HIV1 activity against primary isolates in TZM-bl and PM1 cell lines}

The anti-HIV1 activity was tested against Cell-free (CF) and Cell-associated (CA) X4 tropic (HIV-1 UG070) and R5 tropic (HIV-1 ${ }_{\text {VB59) }}$ primary isolates in TZM-b1 and PM1 cell lines.

The procedure for anti-HIV1 activity against primary isolates in TZM-bl cell lines followed was same as mentioned above for anti-HIV1 activity against laboratory adapted strains. The results were expressed as percentage inhibition calculated using following equation
The results were expressed as $\mathrm{IC}_{80}(80 \%$ inhibitory concentration).

The anti-HIV activity against primary isolates was also evaluated in PM1 cell lines using 24-well plate (Corning, USA). In the cell free assay, $20 \mathrm{TCID}_{50}$ the viral stock (HIV-1 ${ }_{\text {UG070 }}$ and HIV-1 $1_{\text {VB59 }}$ ) was pre-treated with sub toxic concentrations of the extracts/fractions, before addition onto the cells $\left(5 \times 10^{4}\right.$ cells/well). Whereas, in the cell associated assay, the PM1 cells $\left(5 \times 10^{4}\right.$ cells/well $)$ were pre-infected with $20 \mathrm{TCID}_{50}$ of the viral stock and then exposed to the extracts/fractions [72]. The virus growth was monitored by Vironostika ${ }^{\circ} 24$ antigen ELISA (Biomerieux, France). Dextran sulphate and AZT were used as positive controls for cell free and cell associated assays respectively. The percent inhibition was calculated by comparing activity in absence of the extracts/fractions/control drug using the formula mentioned above and the results were expressed as $\mathrm{IC}_{80}$.

\section{Toxicity testing using Transwell epithelial model Cytotoxicity assay}

The toxicity of selected plant extract was determined in HEC-1A using similar protocol as described for TZM-bl cells, only with a difference of the read out system, i.e. LDH cytotoxicity detection kit (Roche Diagnostics, Germany).

\section{Determination of epithelial integrity in Transwell dual- chamber system}

The epithelial integrity was determined as described by Gali et al., [73]. Briefly, HEC-1A cells $\left(1 \times 10^{5} / 100 \mu \mathrm{l}\right)$ were cultured for 7 days on the apical chamber of a Laminin coated dual-chamber Transwell ${ }^{\circ}$ system (growth area: $0.3 \mathrm{~cm}^{2}$, pore size: $3.0 \mu \mathrm{m}$ ) (Corning Costar Corp, USA). After 7 days incubation, two-fold serial dilutions of test preparations $(100 \mu \mathrm{l})$ were added on to the HEC-1A cells and incubated for $24 \mathrm{~h}\left(37^{\circ} \mathrm{C}, 5 \% \mathrm{CO}_{2}\right)$. The test preparations were removed and $100 \mu \mathrm{l}$ of a $1 / 20$ dilution of yellow-green fluorescent microspheres (FluoSpheres ${ }^{\circ}$ sulphate microspheres, Molecular Probes Europe NV, Netherlands) were added in the apical chamber. After $24 \mathrm{~h}, 100 \mu \mathrm{l}$ of medium was harvested from the basal chamber and the fluorescence was measured using a fluorometer (Perkin Elmer, USA). Untreated HEC-1A cells and 1\% Nonoxynol-9 were used as controls for measuring percent transmission.

\section{Results}

\section{Preliminary phytochemical investigation}

The preliminary phytochemical evaluation of plant extracts for the presence of steriods, flavanoids, alkaloids,

$\%$ Inhibition $=1-[($ luminescence in presence of the test extract or fraction

-luminescence of uninfected control cells/luminescence of cells infected with virus

-luminescence of uninfected control cells) $] \times 100$ 
saponins, tannins and phenolic acids was done for 10 plants extracts from 8 different families. Steroids were not present in T. procumbens, M. philippinensis, $R$. centifolia and $A$. squamosa extracts and the Saponins in $T$. procumbens and $A$. reticulate extract. Only flavanoids was present in $T$. procumbens extract while it was not present in S. potaotorum extract (Table 3).

\section{Determination of cytotoxicity in TZM-bl and PM1 cell lines}

Six methanolic extracts, two aqueous extracts and two hydroalcoholic extracts of 10 medicinal plants were examined for their ability to inhibit HIV-1 entry and replication. The in vitro toxicity of these extracts to TZM-bl cells was investigated by MTT assay. Methanolic extracts of, $A$. aspera, hydroalcoholic extract of $A$. squamosa and water extract of $F$. benghalensis tested were relatively non-toxic to TZM-bl cells at a $\mathrm{CC}_{50}$ value between 51 and $72 \mu \mathrm{g} / \mathrm{ml}$. The $\mathrm{CC}_{50}$ values of other extracts such as methanolic extract of, $R$. centifolia, S. potatorum and aqueous extract of $F$. infectoria were found to be comparatively higher ranging between 118 and $147 \mu \mathrm{g} / \mathrm{ml}$. However, methanolic extract of $A$. reticulate was found to be toxic at a very low concentration $\left(\mathrm{CC}_{50}=11 \mu \mathrm{g} / \mathrm{ml}\right)$ as compared to the other extracts (Tables 4 and 5 ).

Cytotoxicity of plant extracts, A. aspera, F. benghalensis, $R$. centifolia, S. potatorum, $F$. infectoria and A. squamosa showing activity in preliminary anti-HIV-1 assay was carried out in PM1 cells using trypan blue dye exclusion assay. The $50 \%$ cytotoxicity was observed at a concentrations ranging from $2.9-46 \mu \mathrm{g} / \mathrm{ml}$. Aqueous extract of $F$. benghalensis was toxic at a very low concentration as compared to other extracts (Table 5).
Preliminary screening for anti-HIV1 activity against laboratory adapted strains in TZM-bl cell lines

Plant extracts of $A$. aspera, $F$. benghalensis, $R$. centifolia, S. potatorum, F. infectoria and A. squamosa showed inhibition of HIV-1 $1_{\text {IIIB }}$ and HIV-1 Ada5 $_{\text {laboratory adapted }}$ strains in both cell free and cell associated assays. Aqueous extract of $F$. infectoria revealed significant activity against the laboratory adapted strains with estimated $\mathrm{IC}_{80}$ in the range of $4.24-125 \mu \mathrm{g} / \mathrm{ml}$ giving TI of 189,49 and 27 in cell free HIV-1 $1_{\text {IIIB }}, \mathrm{HIV}-1_{\text {Ada5 }}$ and cell associated HIV-1 $1_{\text {IIIB }}$ respectively. This was followed by methanolic extract of $A$. aspera which showed activity with preliminary $\mathrm{IC}_{80}$ in the range of $18-35 \mu \mathrm{g} / \mathrm{ml}$ giving $\mathrm{TI}$ of 14,35 and 13 in cell free HIV-1 $1_{\text {IIIB }}, \mathrm{HIV}-1_{\text {Ada } 5}$ and cell associated HIV-1 $1_{\text {IIIB }}$ respectively. Aqueous extract of $F$. benghalensis exhibited activity in both laboratory adapted strains with estimated $\mathrm{IC}_{80}$ in the range of 18 $35 \mu \mathrm{g} / \mathrm{ml}$ giving TI between12-32. Methanolic extract of $S$. potatorum showed activity with preliminary $\mathrm{IC}_{80}$ in the range of $29.17-79.35 \mu \mathrm{g} / \mathrm{ml}$ giving estimated TI of 24 in cell free HIV-1 $1_{\text {Ada5 }}$ strain. Methanolic extract of $R$. centifolia and hydroalcoholic extract of A. squamosa displayed very low activity (estimated TI in the range of 1-6). Hydroalcoholic extract of A. lebbeck, methanolic extract of T. procumbens, M. philippinensis and A. reticulate did not demonstrate any activity against cell free and cell-associated laboratory adapted HIV-1 strains.

\section{Confirmation of anti-HIV activity against primary isolates in TZM-bl and PM1 cell lines}

The plant extracts showing activity in preliminary screening against laboratory adapted strains were further screened both cell free and cell associated assays against primary isolates HIV-1 $1_{\mathrm{UG} 070}$ and HIV-1 $1_{\mathrm{VB} 59}$ in TZM-b1

Table 4 Inhibitory concentrations and therapeutic index of plant extracts against Laboratory adapted HIV-1 $1_{\text {IIIB }}$ and HIV-1 Ada5 $_{\text {Strains }}$ in TZM-bl cell lines

\begin{tabular}{|c|c|c|c|c|c|c|c|c|c|c|c|c|c|c|}
\hline \multirow{3}{*}{$\begin{array}{l}\text { Sr. } \\
\text { No. }\end{array}$} & \multirow[t]{3}{*}{ Plant Extract } & \multirow{3}{*}{$\begin{array}{l}\mathrm{CC}_{50} \\
(\mu \mathrm{g} / \\
\mathrm{ml})\end{array}$} & \multicolumn{4}{|l|}{ IC50 } & \multicolumn{4}{|l|}{$\mathrm{IC} 80$} & \multicolumn{4}{|c|}{ Therapeutic Index } \\
\hline & & & \multicolumn{2}{|l|}{ CF } & \multicolumn{2}{|l|}{ CA } & \multicolumn{2}{|l|}{ CF } & \multicolumn{2}{|l|}{ CA } & \multicolumn{2}{|l|}{$\mathrm{CF}$} & \multicolumn{2}{|l|}{ CA } \\
\hline & & & IIIB & Ada5 & $\| \mathrm{IB}$ & Ada5 & $\| \mathrm{I}$ & Ada5 & IIIB & Ada5 & $\| I B$ & $\overline{\text { Ada5 }}$ & $\| \mathrm{IIB}$ & $\overline{\text { Ada5 }}$ \\
\hline 1 & A. lebbeck & 203 & \multicolumn{12}{|c|}{ No activity } \\
\hline 2 & T. procumbens & 62 & \multicolumn{12}{|c|}{ No activity } \\
\hline 3 & A. aspera & 69 & 8.3 & 2.3 & 4.1 & 28.4 & 18 & 21 & 26 & 35 & 14 & 35 & 13 & 3 \\
\hline 4 & F. benghalensis & 72 & 6 & 6 & 5.2 & 2.25 & 9.6 & 9.6 & 8.32 & 3.6 & 12 & 12 & 14 & 32 \\
\hline 5 & M. philippinensis & 71 & \multicolumn{12}{|c|}{ No activity } \\
\hline 6 & R. centifolia & 132 & 13.6 & 24.8 & 51.9 & 75.4 & 30.4 & 45.2 & 96.1 & 118 & 5 & 6 & 1 & 1 \\
\hline 7 & S. potatorum & 124 & 4.97 & 3.65 & 18.51 & 17.67 & 29.17 & 35.89 & 79.35 & 78.43 & 10 & 24 & 8 & 7 \\
\hline 8 & A. reticulata & 11 & \multicolumn{12}{|c|}{ No activity } \\
\hline 9 & F. infectoria & 147 & 1.18 & 2.97 & 4.97 & 87.38 & 4.24 & 8.6 & 52.49 & $>125$ & 189 & 49 & 27 & 2 \\
\hline 10 & A. squamosa & 51 & \multicolumn{2}{|c|}{ No activity } & 23 & 11.3 & \multicolumn{2}{|c|}{ No activity } & 27 & 20 & 2 & 4 & 2 & 3 \\
\hline
\end{tabular}

$\mathrm{CC}_{50-50 \%}$ cytotoxic concentration, $\mathrm{IC}_{50}-50 \%$ inhibitory concentration

$\mathrm{IC}_{80}-80 \%$ inhibitory concentration, CF- Cell Free, CA- Cell Associated 
Table 5 Inhibitory concentrations of plant extracts against Primary isolates HIV-1UG070 and HIV-1VB59 in TZM-bl and PM1 cell lines

\begin{tabular}{|c|c|c|c|c|c|c|c|c|c|c|}
\hline \multirow{4}{*}{$\begin{array}{l}\text { Extracts/ Fractions/ } \\
\text { Controls }\end{array}$} & \multicolumn{5}{|c|}{ TZM-bl assay } & \multicolumn{5}{|c|}{ PM-1 assay } \\
\hline & \multirow{3}{*}{$\begin{array}{l}\mathrm{CC}_{50} \\
(\mu \mathrm{g} / \\
\mathrm{ml})\end{array}$} & \multicolumn{4}{|c|}{$\mathrm{IC}_{80}(\mu \mathrm{g} / \mathrm{ml})$} & \multirow{3}{*}{$\begin{array}{l}\mathrm{CC}_{50} \\
(\mu \mathrm{g} / \\
\mathrm{ml})\end{array}$} & \multicolumn{4}{|c|}{$\mid \mathrm{C}_{80}(\mu \mathrm{g} / \mathrm{ml})$} \\
\hline & & \multicolumn{2}{|l|}{$\begin{array}{l}\mathrm{CF} \\
\text { HIV-1 }\end{array}$} & \multicolumn{2}{|l|}{$\begin{array}{l}\text { CA } \\
\text { HIV-1 } \\
\end{array}$} & & \multicolumn{2}{|c|}{$\begin{array}{l}\text { CF } \\
\text { HIV-1 } \\
\end{array}$} & \multicolumn{2}{|l|}{$\begin{array}{l}\text { CA } \\
\text { HIV-1 }\end{array}$} \\
\hline & & $\begin{array}{l}\text { UG } \\
070\end{array}$ & $\begin{array}{l}\text { VB } \\
59\end{array}$ & $\begin{array}{l}\text { UG } \\
070\end{array}$ & $\begin{array}{l}\text { VB } \\
59\end{array}$ & & $\begin{array}{l}\text { UG } \\
070\end{array}$ & $\begin{array}{l}\text { VB } \\
59\end{array}$ & $\begin{array}{l}\text { UG } \\
070\end{array}$ & $\begin{array}{l}\text { VB } \\
59 \\
\end{array}$ \\
\hline A. aspera & 69 & 4.8 & $<19.53$ & 26 & 53 & 10.7 & 2.6 & 8.4 & 1 & 1.6 \\
\hline F. benghalensis & 72 & $<78$ & $<156$ & $<156$ & $<78$ & 2.9 & 3.5 & 2.9 & NA & NA \\
\hline R. centifolia & 132 & 17 & 33.5 & 60.5 & $>125$ & 20 & 3.6 & 6.8 & 2.2 & 9 \\
\hline S. potatorum & 124 & $<31.25$ & 80 & 60 & 105 & 46 & 29 & NA & 6 & 8.3 \\
\hline F. infectoria & 147 & 18 & 22 & 42 & 73 & 28 & 2 & 29 & NA & NA \\
\hline A. squamosa & 51 & 27 & 27 & 25 & 26 & 15.12 & NA & NA & 0.8 & 0.8 \\
\hline \multirow[t]{2}{*}{ Control } & 5553 & 6.43 & 4.5 & - & - & 4978 & 9.18 & 16.54 & - & - \\
\hline & 782 & - & - & 8.01 & 18.70 & 998.5 & - & - & 8244.35 & $12,079.33$ \\
\hline
\end{tabular}

$C_{50} 50 \%$ cytotoxic concentration, $I C_{80} 80 \%$ inhibitory concentration, DS Dextran Sulphate, AZT Azidothymidine, CF Cell Free, CA Cell Associated Legend: The plant extracts showing $80 \%$ inhibition of HIV-1 primary isolates (UG070 \& VB59) in TZM-bl cell line by cell free and cell associated assay with positive controls dextran sulphate and azidothymidine respectively

and PM1 cell lines for confirmation of their anti-HIV1 activity.

In TZM-b1 cell lines methanolic extract of $A$. aspera and hydroalcoholic extract of $A$. squamosa exhibited a very good activity with lowest estimated $\mathrm{IC}_{80}$ of $4.8-$ $53 \mu \mathrm{g} / \mathrm{ml}$ and $25-27 \mu \mathrm{g} / \mathrm{ml}$ respectively against primary isolates of HIV-1 strains. This was followed by aqueous extract of $F$. infectoria, methanolic extract of $S$. potatorum and R. centifolia and aqueous extract of F. benghalensis with preliminary $\mathrm{IC}_{80}$ in the range of 18 $73 \mu \mathrm{g} / \mathrm{ml},<31.25-105 \mu \mathrm{g} / \mathrm{ml}, 17->125 \mu \mathrm{g} / \mathrm{ml}$, and $<78$ $<156 \mu \mathrm{g} / \mathrm{ml}$ respectively (Table 5 ).

In PM1 cell lines, methanolic extract of $A$. aspera and $R$. centifolia showed activity with estimated $\mathrm{IC}_{80}$ ranging $1-9 \mu \mathrm{g} / \mathrm{ml}$. Aqueous extract of $F$. benghalensis exhibited activity at preliminary $\mathrm{IC}_{80}$ of $2.9-3.5 \mu \mathrm{g} / \mathrm{ml}$ in cell free assay. Methanolic extract of $S$. potatorum exhibited activity at $\mathrm{IC}_{80}$ of $6-29 \mu \mathrm{g} / \mathrm{ml}$ except for $\mathrm{HIV}-1_{\mathrm{VB} 59}$ cell free assay. The hydroalcoholic extract of A. squamosa showed very good activity at lower concentration $0.8 \mu \mathrm{g} /$ $\mathrm{ml}$ in cell associated assay. Aqueous extract of $F$. infectoria showed activity in cell free assay at a concentration ranging $2-29 \mu \mathrm{g} / \mathrm{ml}$ (Table 5). The representative dose response bar graphs for $A$. aspera and R. centifolia, in cell free and cell associated assays for TZMb1 and PM1 are given in Additional file 1: (Figures S1 to S5).

\section{Toxicity testing using Transwell epithelial model}

Amongst the three extracts which showed highest activity, methanolic extract of $R$. centifolia exhibited least toxicity both inTZM-b1 and PM1 cell lines, therefore it was further tested for in vitro activity against HEC-1A cells and demonstrated minimal cytotoxicity with $\mathrm{CC}_{50}$ of $1443 \mu \mathrm{g} /$ $\mathrm{ml}$. Epithelial integrity of HEC-1A in Transwell dual- chamber system was maintained with only $1 \%$ relative fluorescence (percent of positive control) detected after treatment with $500 \mu \mathrm{g} / \mathrm{ml}$ of methanolic extract of $R$. centifolia. At higher concentration of $1000 \mu \mathrm{g} / \mathrm{ml}$ integrity was affected with $24 \%$ leaked fluorescence relative to positive control (Fig. 1).

\section{Discussion}

Natural products continue to be major sources of innovative therapeutic agents for treatment of infectious diseases, and their exploration has been one of the most successful strategies for the discovery of medicines. The development of new microbicides as preventive interventions is a promising area in AIDS research [3]. They could be valuable addition in prevention of sexual transmission of HIV-1 and could be an important way to reduce the number of cases of HIV infection globally $[74,75]$. Currently available anti-HIV drugs are chemically synthesized and are often limited by side effects and emergence of drug resistance [76].

In order to find such potential anti-HIV agents from natural sources, ten traditional medicinal plants from India were studied for their inhibitory effects against laboratory adapted strains HIV-1 IIIB, HIV-1Ada5 and primary isolates HIV-1UGO70, HIV-1VB59 in TZM-b1 and primary isolates HIV-1UGO70, HIV-1VB59 in PM1 cell lines. HIV viruses can spread in the body via either a cell-free (virus floating free in plasma) mode or a cell associated (virus particles that remain attached to or within the host cell after replication) mode involving direct cell-cell contact. Hence all the selected plant extracts were evaluated to depict their mechanism of action, whether they will act as an entry inhibitor or at the HIV replication stage [77]. 


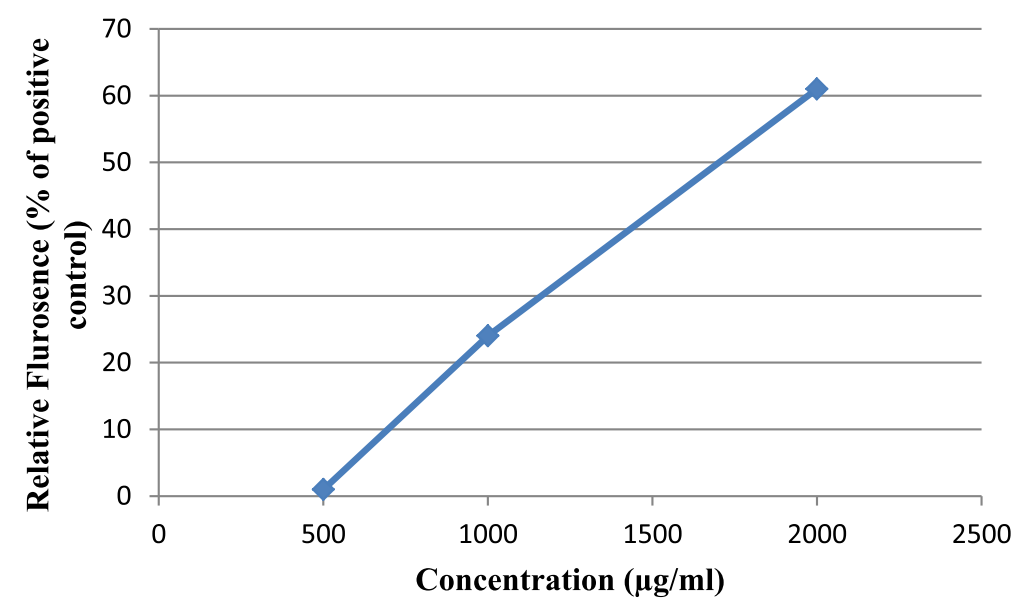

Fig. 1 Plot of Relative Fluroscence (\%) Vs Concentration $(\mu \mathrm{g} / \mathrm{ml})$ determining epithelial integrity of $R$. centifolia by measuring permeability to FluoSpheres using the Dual-Transwell Epithelial Model

The selected plant extracts were subjected to high throughput (cost-effective, quick and reproducible) TZM-bl assay model which is useful for preliminary screening allowing screening of large number of products against HIV [70, 78]. The results presented here indicate that the methanolic extracts of aerial parts of $A$. aspera, leaves of $R$. centifolia and seeds of S. potatorum and aqueous extract of leaves of $F$. benghalensis and $F$. infectoria possess anti-HIV properties of therapeutic interest inhibiting HIV-1 virus at an estimated TI of 3$35,1-6,7-24,12-32$, and $2-189$ respectively against laboratory adapted strains and at a very low preliminary $\mathrm{IC}_{80}$ ranging from $4.8-26,17-125,31-105,78-156$ and $18-73 \mu \mathrm{g} / \mathrm{ml}$ respectively against primary isolates using TZM-b1 assay.

The lead extracts were also confirmed for anti-HIV activity in PM1 cell line which supports persistent HIV-1 infection [72]. The PM1 cell line have been reported to be comparable to peripheral blood mononuclear cells (PBMCs) for culturing of any of the HIV-1 strains and subtypes and thus provide a valuable research tool for studying new anti-HIV therapies [79]. This cell line has been previously used for studying the anti-HIV1 properties of the polyherbal cream Basant [80]. Hence PM-1 was used for confirming the anti-HIV activity of the methanolic extracts of aerial parts of $A$. aspera and leaves of $R$. centifolia which showed anti-HIV activity $\left(\mathrm{IC}_{80}\right)$ ranging between 1 and 8.4 and $2.2-6.8 \mu \mathrm{g} / \mathrm{ml}$ respectively. These extracts may potentially inhibit the entry and also inhibit HIV-1 replication if the virus enters the vaginal cells. However further work on more replicates and wider concentration range studies are required for confirmation. Future studies on PBMCs for qualifying the results should also be considered.
Our earlier work has shown that methanolic extract of $R$. centifolia has also shown activity against four strains of $N$. gonorrhoeae [81]. It substantially lacks cytotoxicity even at high concentrations $\left(\mathrm{CC}_{50}\right.$ greater than $\left.1 \mathrm{mg} / \mathrm{ml}\right)$ when tested in vitro on HEC-1A cell line (endometrial origin) and maintained its epithelial integrity when studied in Transwell model at concentrations up to $500 \mu \mathrm{g} /$ $\mathrm{ml}$ thus showing potential for investigating it further as candidate anti-HIV microbicide.

As per the literature these extracts have not been further analyzed chemically, although the active components such as oleanolic acid and pomolic acid isolated from Rosa wodsii leaves the other species of Rosa, have been reported to inhibit HIV replication in acutely infected $\mathrm{H} 9$ cell growth at $\mathrm{IC}_{50}$ of $40 \mu \mathrm{g} / \mathrm{ml}[56,57]$. The literature indicates the phytosteroids, polyphenols and saponins present in the methanolic leaf extract of $A$. aspera are responsible for its anti-fertility effect [66] and methanolic root extract possess anti-herpes virus activity at $\mathrm{EC}_{50}$ of $64.4 \mu \mathrm{g} / \mathrm{ml}$ for $\mathrm{HSV}-1$ and $72.8 \mu \mathrm{g} / \mathrm{ml}$ for HSV-2 [82]

The other selected medicinal plants extract showed anti-HIV activity against at least any one of the assay model except for hydroalcoholic extract of whole pods of A. lebbeck, methanolic extract of aerial parts of T. procumbens, methanolic extract of leaves of M. philippinenis and methanolic extract of leaves of $A$. reticulate, they were incapable of showing anti-HIV1 activity against cell free and cell associated HIV-1 ${ }_{\text {IIIB }}$, HIV-1 $1_{\text {Ada } 5}$ laboratory adapted strains and HIV-1 $1_{\mathrm{UG070}}, \mathrm{HIV}-1_{\mathrm{VB} 59}$ primary isolates in TZM-b1 and PM1 cell lines. It's worth mentioning that these plants were selected on basis of their sub species showing activity against other strains and primary isolates of HIV and the same species having contraceptive and activity related to this infectious 
disease. The inactivity of these plants against our test strains and primary isolates of HIV does not prove that they do not possess anti-HIV1 activity. These plants can be taken further for the activity against other strains and primary isolates of HIV virus using other anti-HIV assays.

Some plants extract such as $F$. benghalensis, S. potatorum and $F$. infectoria showed moderate to mild anti-HIV1 activity. These plants extracts had variable activities across the assays presented in this study where the extract exhibited inhibition of one strain of the primary isolates in one assay but did not inhibit the same primary isolates in another assay model. Aqueous extract of leaves of $F$. benghalensis showed anti-HIV1 activity against all HIV-1 laboratory adapted strains and primary isolates using TZM-b1 assay (TI: 1232, $\mathrm{IC}_{80}: 78-156 \mu \mathrm{g} / \mathrm{ml}$ ) but did not inhibit cell associated primary isolates in PM1 assay. Methanolic extract of seeds of $S$. potatorum showed anti-HIV1 activity against all HIV-1 laboratory adapted strains and primary isolates using TZM-b1 assay (TI: 7-24, $\mathrm{IC}_{80}: 31.25-105 \mu \mathrm{g} / \mathrm{ml}$ ) but was not capable of inhibiting cell free primary isolate HIV- $1_{\text {VB59 }}$ in PM1 assay. Aqueous extract of leaves of $F$. infectoria showed anti-HIV1 activity against all HIV-1 laboratory adapted strains and primary isolates using TZMb1 assay (TI: $2-189, \mathrm{IC}_{80}: 18-73 \mu \mathrm{g} / \mathrm{ml}$ ) but did not inhibit cell associated primary isolates in PM1 assay. Hence these extracts may not altogether be classified as extracts not having anti-HIV1 inhibitory potential.

Hydroalcoholic extract of seeds of A. squamosa exhibited activity against all HIV-1 laboratory adapted strains and primary isolates using TZM-b1 assay (TI: $2-4, \mathrm{IC}_{80}$ : $26-27 \mu \mathrm{g} / \mathrm{ml}$ ) but was not capable of inhibiting cell free primary isolates in PM1 assay. This plant extract has a some potential to be explored further and may be used supplementary as a replication inhibitor.

\section{Conclusion}

To conclude the study, out of 10 plants screened for anti-HIV activity using TZM-b1 and PM1 assays, methanolic extracts of aerial parts of $A$. aspera and leaves of $R$. centifolia has prospective anti-HIV1 potential as an entry and replication inhibitors. Hence these experimental moieties may have favourable implications on the prevention or management of HIV/AIDS. Additionally methanolic extract of leaves of $R$. centifolia have shown good safety and maintained the epithelial integrity on HEC-1A cells. Plant extracts are complex mixtures of many compounds. Some compounds may mask the antiHIV1 potential of plant extract due to their cytotoxicity. Therefore our next step would be isolating the phytoconstituents and increasing the chances to find active anti HIV1 compounds with low cytotoxicity.

\section{Supplementary information}

Supplementary information accompanies this paper at https://doi.org/10. 1186/s12906-020-2816-X.

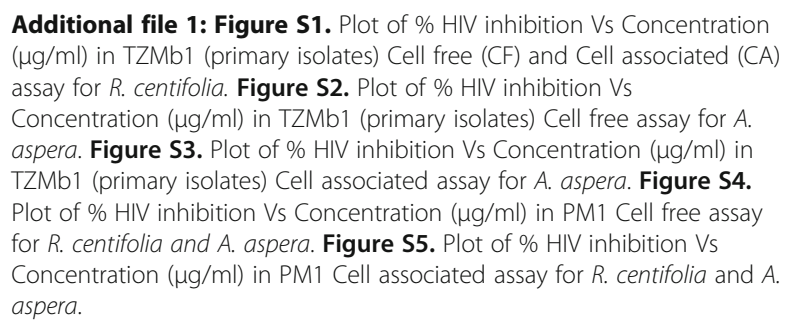

Additional file 1: Figure S1. Plot of \% HIV inhibition Vs Concentration $(\mu \mathrm{g} / \mathrm{ml})$ in TZMb1 (primary isolates) Cell free (CF) and Cell associated (CA) assay for $R$. centifolia. Figure S2. Plot of \% HIV inhibition Vs

Concentration $(\mu \mathrm{g} / \mathrm{ml})$ in TZMb1 (primary isolates) Cell free assay for $A$. aspera. Figure S3. Plot of \% HIV inhibition Vs Concentration $(\mu \mathrm{g} / \mathrm{ml})$ in TZMb1 (primary isolates) Cell associated assay for A. aspera. Figure S4. Plot of \% HIV inhibition Vs Concentration $(\mu \mathrm{g} / \mathrm{ml})$ in PM1 Cell free assay for $R$. centifolia and A. aspera. Figure S5. Plot of \% HIV inhibition Vs Concentration $(\mu \mathrm{g} / \mathrm{ml})$ in PM1 Cell associated assay for $R$. centifolia and A. aspera.

\section{Abbreviations}

AIDS: Acquired Immunodeficiency Syndrome; CA: Cell-associated; CC 50 : 50\% cytotoxic concentration; CF: Cell-free; DMEM: Dulbecco's modified Eagle's medium; DMSO: Dimethyl Sulphoxide; FBS: Fetal Bovine Serum; HAART: Highly Active Antiretroviral Therapy; HEC-1A: Human Endometrial Adenocarcinoma; HIV: Human Immunodeficiency Virus; HSV: Herpes Simplex Virus; $I_{80}$ : 80\% inhibitory concentration; LDH: Lactate Dehydrogenase; MTT: 3-(4,5-dimethythiazol-2-yl)-2,5-diphenyl tetrazolium bromide; OD: Optical Density; PBMC: Peripheral Blood Mononuclear Cells; PHA P: Phytohemagglutinin P; RPMI-1640: Roswell Park Memorial Institute1640 Medium; TCID 50 : Median Tissue Culture Infectious Dose; TI: Therapeutic Index

\section{Acknowledgments}

The authors would like to thank Sh. V. Chelladurai, Research Officer (Botany), S-III, Survey of Medicinal Plants Unit - Siddha, Palayamkottai (Rtd.) and S.N.D.T. Women's University campus for supplying plant materials and specimens for authentication. The authors would also like to thank Botanical Survey of India for carrying out authentication of the plant specimens.

\section{Authors' contributions}

AP participated in the design and coordination of the study, carried out the extraction and standardization studies and drafted the manuscript. NP, MP and AW participated and performed the cytotoxicity and anti-viral assays. NJ and AW participated and performed cytotoxicity and anti-viral assays and edited the manuscript. SK designed the research work and participated in cytotoxicity and anti-viral assays and gave final approval for its publication. KKS designed the research work, overviewed the extraction and

standardization studies and edited and revised the manuscript critically for important intellectual content and gave final approval for its publication. All authors read and approved the final manuscript.

\section{Funding}

This study was supported by grant BT/PR7965/Med/14/1203/2006 from Department of Biotechnology (DBT, New Delhi) and Indian Council of Medical Research (ICMR, New Delhi).

\section{Availability of data and materials}

The datasets used and/or analysed during the current study available from the corresponding author on reasonable request.

Ethics approval and consent to participate

Not applicable

\section{Consent for publication}

Not applicable.

\section{Competing interests}

The authors declare that they have no competing interests.

\section{Author details}

${ }^{1}$ C. U Shah College of Pharmacy, S.N.D.T. Women's University, Santacruz West, Mumbai 400049, India. ${ }^{2}$ National AIDS Research Institute, 73, 'G'-Block, MIDC, Bhosari, Pune 411 026, India. ${ }^{3}$ School of Pharmacy and Biomedical Sciences, Faculty of Clinical and Biomedical Sciences, University of Central Lancashire, Preston PR1 2HE, UK. 
Received: 18 July 2019 Accepted: 15 January 2020 Published online: 06 March 2020

\section{References}

1. United Nations Programme on HIV/AIDS (UNAIDS), UNAIDS data 2019. Available online: https:/www.unaids.org/en/resources/fact-sheet https://www.hiv.gov/hivbasics/overview/data-and-trends/global-statistics Accessed Oct 2019.

2. Rege A, Ambaye RY, Deshmukh RA. In-vitro testing of anti-HIV activity of some medicinal plants. Indian J Nat Prod Resour. 2010;1(2):193-9.

3. D'Cruz OJ, Uckun FM. Clinical development of microbicides for the prevention of HIV infection. Curr Pharm Des. 2004;10(3):315-36.

4. Gupta RS, Kachhawa JB, Chaudhary R. Antifertility effects of methanolic pod extract of Albizia lebbeck (L.) Benth in male rats. Asian J Androl. 2004;6:1559.

5. Karuppannan K, Subramanian D, Priyadharshini VS. Phytopharmacological properties of Albizia species: a review. Int J Pharm Pharm Sci. 2013;5(3):70-3.

6. Salahdeen HM, Yemitan OK, Alada AR. An effect of aqueous leaf extract of Tridax procumbens on blood pressure and heart rate in rats. Afr J Biomed Res. 2004;7:27-9.

7. Mahato RB, Chaudhary RP. Ethnomedicinal study and antibacterial activities of selected plants of Palpa district, Nepal. Sci World. 2005;3(3):26-31.

8. Saxena VK, Albert S. b-Sitosterol-3-O-b-D-xylopyranoside from the flowers of Tridax procumbens Linn. J Chem Sci. 2005;117(3):263-6.

9. Vilwanathan R, Shivashangari KS, Devak T. Hepatoprotective activity of Tridax procumbens against $\mathrm{d}$ galactosamine/lipopolysaccharide-induced hepatitis in rats. J Ethnopharmacol. 2005;101:55-60.

10. Bhagwat DA, Killedar SG, Adnaik AS. Anti-diabetic activity of leaf extract of Tridax procumbens. Intnl J Green Pharma. 2008:2:126-8.

11. Oladunmoye MK, Nutan Modi M, Dezzutti CS, Kulshreshtha S, Rawat A, Srivastava S, et al. Immunomodulatory effects of ethanolic extract of Tridax procumbens on swiss albino rats orogastrically dosed with Pseudomonas aeruginosa (NCIB 950). Int J Tropical Med. 2006;1(4):152-5.

12. Vishnupriya P, Radhika K, Sivakumar R, Sri Ramchandra M, Prameela Devi V, Rao S. Evaluation of anticancer activity of T. procumbens flower extracts on PC3 cell lines. Int J Adv Pharm Sci. 2011;2(1):28-30.

13. Jayakumar T, Sridhar MP, Bharathprasad TR, Ilayaraja MG, S Balasubramanian MP. Experimental studies of Achyranthes aspera $(\mathrm{L})$ preventing nephrotoxicity induced by lead in albino rats. J Health Sci. 2009;55(5):701-8.

14. Khanna AK, Chander R, Singh C, Srivastava AK, Kapoor NK. Hypolipidemic activity of Achyranthes aspera L. in normal and triton induced hyperlipemic rats. Indian J Exp Biol. 1992;30(2):128-30.

15. Chakraborty A. Cancer chemo preventive activity of Achyranthes aspera leaves on Espstein bar virus activation and two stages mouse skin carcinogenesis. Cancer Lett. 2002;177(1):25-31.

16. Mishra SH, Bafna AR. Effect of methanol extract of Achyranthes aspera Linn. on rifampicin-induced hepatotoxicity in rats. Ars Pharm. 2004;45(4):343-51.

17. Shibeshi W, Makonnen E, Zerihun L, Debella A. Estrogenic activity in Ethanolic extract of Bupleram marginatum. J Pharmacol Afr Health Sci. 2006; 6(2):108-12

18. Saravanan $P$, Ramasamy $V$, Shivakumar $T$. Antimicrobial activity of leaf extracts of Achyranthes aspera L. Asian J Chem. 2008;20(1):823-5.

19. Gayathri DS, Archanah A, Abiramasundari P, Priya V, Uma K, Abirami T. Pharmacological activities of Achyranthes aspera, an overview. Indian J Nutr Diet. 2009:46(12):485-90.

20. Barua CC, Talukdar A, Begum SA, Buragohain B, Roy JD, Borah RS, Lahkar M. Antidepressant like effects of Achyranthes aspera $L$. animals models of depression. Pharmacol. 2009;2:587-94.

21. Paul DD, De KM, Ali K, Chatterjee DK, Nandi DG. Effects of various extracts from the roots of Achyranthes aspera. Contraception. 2010;81(4):355-61.

22. Khan MT, Ahmad K, Alvi MN, Mansoor B, Asif SM, Khan FZ, et al. Antibacterial and irritant activities of organic solvent extracts of Agave americana Linn., Albizia lebbeck Benth., Achyranthes aspera Linn. and Abutilon indicum Linn. - a preliminary investigation. Pakistan J Zool. 2010; 2(1):93-7.

23. Gabhe $\mathrm{S}$, Tatke $\mathrm{P}$, Khan T. Evaluation of the immunomodulatory activity of the methanol extract of Ficus benghalensis roots in rats. Indian J Pharm. 2006;38(4):271-5.

24. Parekh J, Jadeja D, Chanda S. Efficacy of aqueous and methanol extracts of some medicinal plants for potential antibacterial activity. Turk J Biol. 2005; 29:203-10.
25. Gayathri M, Krishnan K. Antidiabetic and ameliorative potential of Ficus bengalensis bark extract in Streptozotocin induced diabetic rats. Indian J Clin Biochem. 2008;23(4):394-400.

26. Shukla R, Gupta S, Gambhir JK, Prabhu KM, Murthy PS. Antioxidant effect of aqueous extract of the bark of Ficus bengalensis in hypercholesterolaemic rabbits. J Ethnopharmacol. 2004:92:47-51.

27. Taur DJ, Nirmal SA, Patil RY, Kharya MD. Antistress and ant allergic effects of Ficus bengalensis bark in asthma. Nat Prod Res. 2007;14:1266-70.

28. Gupta AK, Dwivedi S, Sharma A, Lodhi GS. Evaluation of antihyperlipidemic, hypoglycemic and antioxidant potential of Ficus infectoria methanolic extract in wistar rats. J Pharmacognosy Phytochemistry. 2013;1(6):194-201.

29. Daikonya A, Katsuki S, Wu JB, Kitanaka S. Anti-allergic agents from natural sources (4): anti-allergic activity of new phloroglucinol derivatives from Mallotus philippinensis (Euphorbiaceae). Chem Pharm Bull. 2002;50(12):1566-

30. Thakur SC, Thakur SS, Chaube SK, Singh SP. An etheral extract of Kamala (Mallotus philippinensis (mull. Arg) lam.) seed induce adverse effects on reproductive parameters of female rats. Reprod Toxicol. 2005; 20(1):149-56.

31. Moorthy K, Srinivasan K, Subramanian C, Mohanasundari C, Palaniswamy M. Phytochemical screening and antibacterial evaluation of stembark of Mallotus philippinensis var. Tomentosus. Afr J Biotechnol. 2007;6(13):1521-3.

32. Tanaka R, Nakata T, Yamaguchi C, Wada S, Yamada T, Tokuda H. Potential anti-tumor-promoting activity of 3a-Hydroxy-D: a-friedooleanan2-one from the stem bark of Mallotus philippinensis. Planta Med. 2008;74(4):413-6.

33. Arfan M, Hazrat K, Magdalena K. Antioxidant activity of phenolic fractions of Mallotus philippinensis bark extract. J Food Sci. 2009;27(2):109-17.

34. Ramakrishna S, Geetha KM, Bhaskargopal PW, Kumar SRP, Madav CP, Umachandar L. Effect of Mallotus philippinensis Muell-Arg leaves against hepatotoxicity of carbon tetrachloride in rats. Int J Pharm Sci Res. 2011;2:7483

35. Khan M, Qureshi RA, Hussain M, Mehmood K, Khan RA. Hexane soluble extract of Mallotus philippinensis (lam.) Muell. Arg. root possesses antileukaemic activity. Chem Cent J. 2013;7(1):157-62

36. Roshan R, Kulkarni SG, Tupe SP. Antifungal dimeric Chalcone derivative Kamalachalcone E from Mallotus philippinensis. Nat Prod Res. 2014;28(4):24550 .

37. Hassan A, Nafisa. An investigation of antimicrobial compounds for immunomodulating and anti-adhesion properties. Pak Res Repository. 2003.

38. Sankaranand R. Evaluation of antitussive activity of Rosa centifolia. IJPSR. 2011;2(6):1473-5.

39. Gupta RS, Kanwar M, Rehwani H, Verma SK, Dobhal MP. Contraceptive efficacy of Strychnos potatorum seed extract in male albino rats. Asian J Exp Sci. 2006;20:181-7.

40. Biswas S, Murugesan T, Sinha S, Maiti K, Gayen JR, Pal M, Sah BP. Antidiarrhoeal activity of Strychnos potatorum seed extract in rats. Fitoterapia. 2002;73(1):43-7.

41. Sanmugapriya E, Venkataraman S. Studies on hepatoprotective and antioxidant actions of Strychnos potatorum Linn. seeds on CCl -induced acute hepatic injury in experimental rats. J Ethnopharmacol. 2006;105(142):154-60.

42. Sanmugapriyaa E, Venkataraman S. Antiulcerogenic potential of Strychnos potatorum Linn. seeds on Aspirin plus pyloric ligation-induced ulcers in experimental rats. Phytomedicine. 2007;14(5):360-5.

43. Mallikharjuna PB, Seetharam YN. In vitro antimicrobial screening of alkaloid fractions from Strychnos potatorum. J Chemother. 2009;6(4):1200-4.

44. Ekambaram S, Perumal SS, Venkataraman S. Evaluation of antiarthritic activity of Strychnos potatorum Linn seeds in Freund's adjuvant induced arthritic rat model. BMC Complement Altern Med. 2010;10:56-64.

45. Dhasarathan P, Theriappan P. Evaluation of antidiabetic activity of Strychnos potatorum in alloxan induced diabetic rats. J Med Med Sci. 2011;2(2):670-4.

46. Yuan SSF, HI C, Chen HW, Yeh YT, Kao YH, Lin KH, et al. Annonacin, a monotetrahydrofuran acetogenin, arrests cancer cells at the G1 phase and causes cytotoxicity in a Bax- and caspase-3-related pathway. Life Sci. 2003;72(25):2853-61.

47. Baskar R, Rajeswari V, Sathish KT. In vitro antioxidant studies in leaves of Annona species. Indian J Exp Biol. 2007:45:480-5.

48. Thang TD, Kuo PC, Huang GJ, Hung NH, Huang BS, Yang ML, et al. Chemical constituents from the leaves of Annona reticulata and their inhibitory effects on NO production. Molecules. 2013;18:4477-86.

49. Wu YC, Hung YC, Chang FR, Cosentino M, Wang HK, Lee KH. Identification of ent-16,17-dihydroxykauran-19-oicacid as an anti-HIV principle and 
isolation of the new diterpenoids, annosquamosins a and B from Annona squamosa. J Nat Prod. 1996;59:635-7.

50. Khar A, Pardhasaradhi BW, Reddy M, Ali Mubarak A, KumariLeela A. Antitumour activity of Annona squamosa seed extracts is through the generation of free radicals and induction of apoptosis. Indian J Biochem Biophys. 2004;41:167-72.

51. Mohamed. Hepatoprotective activity of Annona squamosa Linn. on experimental animal model. Int J Appl Res Nat Prod. 2008;1(3):1-7.

52. Jayshree P, Kumar V. Annona squamosa L.: phytochemical analysis and antimicrobial screening. J Pharm Res. 2008;1 (1):34-8.

53. Johns. Antimalarial alkaloids isolated from Annona squamosa. Phytopharmacology. 2011;1(3):49-53.

54. Yadav DK, Singh N. Anti-ulcer constituents of Annona squamosa twigs Fitoterapia. 2011;82(4):666-75.

55. Chandrashekar. Isolation, characterizations and free radical scavenging activity of Annona squamosa leaf. J Pharm Res. 2011;4(3):610-1.

56. Vlietinck AJ, De Bruyne T, Apers S, Pieters LA. Plant-derived leading compounds for chemotherapy of human immunodeficiency virus (HIV) infection. Planta Med. 1988;64(2):97-109.

57. Kashiwada Y, Wang HK, Nagao T, Kitanaka S, Yasuda I, Fujioka T, et al. AntiAIDS agents. 30. Anti-HIV activity of oleanolic acid, pomolic acid, and structurally related triterpenoids. J Nat Prod. 1998;61(9):1090-105.

58. Yu YB, Park JC, Lee JH, Kim GE, Jo SK, Byun MW, et al. Screening of some plant extracts for inhibitory effects on HIV-1 and its essential enzymes. Korean J Pharmacol. 1998;29:338-46.

59. Ramanathan T, Premanathan M, Kathiresan K, Nakashima H, Yamamole N. Studies on some coastal plants for anti-HIV activity. South East Asian Seminar on Herbs and Herbal Medicines, Patna 165. 1999.

60. Nakane H, Arisawa M, Fujita A, Koshimura S, Ono K. Inhibition of HIV reverse transcriptase activity by some fluroglucinol derivatives. FEBS Lett. 1991;286: 83-5.

61. Yadav KN, Kadam PV, Patel JA, Patil MJ. Strychnos potatorum: phytochemical and pharmacological review. Pharmacogn Rev. 2014;8(15):61-6.

62. Singh KK, Parmar S, Tatke PA. Contraceptive efficacy and safety of HerbOshield ${ }^{\text {TM }}$ vaginal gel in rats. Contraception. 2012;85(1):122-7.

63. Taylor RSL, Hudson JB, Manandhar NP, Towers GHN. Antiviral activities of medicinal plants of southern Nepal. J Ethnopharmacol. 1996;53:97-104.

64. Taylor RSL, Manandhar NP, Hudson JB, Towers GHN. Antiviral activities of Nepalese medicinal plants. J Ethnopharmacol. 1996;52:157-63.

65. Lederman MM, Offord RE, Hartley O. Microbicides and other topical strategies to prevent vaginal transmission of HIV. Nat Rev Immunol. 2006;6: 371-82.

66. Workineh S, Eyasu M, Asfaw D, Legesse Z. Phytochemical, contraceptive efficacy and safety evaluations of the methanolic leaves extract of Achyranthes aspera L. in rats. Pharmacologyonline. 2006;3:217-24.

67. Harbourne JB. Phytochemical methods. A guide to modern technique of plant analysis. 3rd ed. London: Chapman and Hall; 1998.

68. Connick E, Campbell T, Schneider K, Wrin T. Relationship between in vitro human immunodeficiency virus type 1 replication rate and virus load in plasma. J Virol. 2003;77(22):12105-12.

69. Mosmann T. Rapid colorimetric assay for cellular growth and survival: application to proliferation and cytotoxicity assays. J Immunol Methods. 1983;65:55-63.

70. Platt EJ, Wehrly K, Kuhmann SE, Chesebro B, Kabat D. Effects of CCR5 and $\mathrm{CD} 4$ cell surface concentrations on infection by macrophage tropic isolates of human immunodeficiency virus type 1. J Virol. 1998;72:2855-64.

71. Verma A, Ranga U, Gupta S. Extracts from Acacia catechu suppress HIV-1 replication by inhibiting the activities of the viral protease and tat. Virol $\mathrm{J}$. 2013;10:309-24.

72. Lusso P, Cocchi F, Balotta C, Markham P, Louie A, Farci P, et al. Growth of macrophage-tropic and primary human immunodeficiency virus type 1 (HIV-1) isolates in a unique CD4+ T-cell clone (PM1): failure to downregulate CD4 and to interfere with cell-line-tropic HIV-1. J Virol. 1995;69(6):3712.

73. Gali Y, Delezay O, Brouwers J, Addad N, Augustijns P, Bourlet T, et al. In vitro evaluation of viability, integrity, and inflammation in genital epithelia upon exposure to pharmaceutical excipients and candidate microbicides. Antimicrob Agents Chemother. 2010;54(12):5105-511.

74. Gaym A. Microbicides-emerging essential pillars of comprehensive HIV/AIDS prevention. Ethiop Med J. 2006;44(4):405-15.

75. Howett MK, Kuhl JP. Microbicides for prevention of transmission of sexually transmitted diseases. Curr Pharm Des. 2005;11(29):3731-46.
76. De Clercq E. New developments in anti HIV chemotherapy. Biochim Biophys Acta. 2002;1587:258-75.

77. Mothes W, Sherer N, Jing J, Zhong P. Virus cell-to-cell transmission. J Virol. 2010:84(17):8360-8.

78. Wei X, Decker JM, Liu H, Zhang Z, Arani RB, Kilby JM, et al. Emergence of resistant human immunodeficiency virus type 1 in patients receiving fusion inhibitor (T-20) monotherapy. Antimicrob Agents Chemother. 2002;46:8961905.

79. Herrera-Carrillo E, Paxton WA, Berkhout B. The search for a T cell line for testing novel antiviral strategies against HIV-1 isolates of diverse receptor tropism and subtype origin. J Virol Methods. 2014;203:88-96 https://doi. org/10.1016/j.jviromet.2014.03.021 Epub 2014 Mar 31.

80. Maselko MB, Joshi RS, Prescott M, Talwar GP, Kulkarni S, et al. Basant, a Polyherbal topical Microbicide candidate inhibits different clades of both CCR5 and CXCR4 tropic, lab-adapted and primary isolates of Human Immunodeficiency Virus-1 in vitro infection. J Virol Antivir Res. 2014;3(4). https://doi.org/10.4172/2324-8955.1000131.

81. Jadhav N, Kulkarni S, Mane A, Kulkarni R, Palshetker A, Singh K, et al. Antimicrobial activity of plant extracts against sexually transmitted pathogens. Nat Prod Res. 2014;27:1-5.

82. Mukherjee H, Ojhaa D, Baga P, Chandel HS, Bhattacharyya S, Chatterjee TK, et al. Anti-herpes virus activities of Achyranthes aspera: an Indian ethnomedicine, and its triterpene acid. Microbiol Res. 2013;168:238-44.

\section{Publisher's Note}

Springer Nature remains neutral with regard to jurisdictional claims in published maps and institutional affiliations.
Ready to submit your research? Choose BMC and benefit from:

- fast, convenient online submission

- thorough peer review by experienced researchers in your field

- rapid publication on acceptance

- support for research data, including large and complex data types

- gold Open Access which fosters wider collaboration and increased citations

- maximum visibility for your research: over $100 \mathrm{M}$ website views per year

At BMC, research is always in progress.

Learn more biomedcentral.com/submissions 